\title{
EXPERIMENTAL ANALYSIS OF VERTICAL VIBRATIONS OF A RAILWAY BOGIE
}

\author{
Mădălina Dumitriu ${ }^{1, *}$, Ioan Cristian Cruceanu ${ }^{2}$ \\ ${ }^{1}$ Department of Railway Vehicles, University Politehnica of Bucharest, Bucharest, Romania \\ ${ }^{2}$ Doctoral School of Transport, University Politehnica of Bucharest, Bucharest, Romania \\ *E-mail of corresponding author: madalinadumitriu@yahoo.com
}

\section{Resume}

The paper presents a study of the vertical vibrations of a bogie of a passenger vehicle, based on the acceleration of the axles and the bogie frames, measured during the running at a constant velocity. To this purpose, the root mean square (RMS) acceleration is calculated for more measurement sequences at different velocities. In principle, the RMS acceleration increases along with the velocity and influence of the variability of the amplitude in the track defects upon the dispersion of the values in the RMS acceleration. Based on the spectral analysis of the measured acceleration, wheel defects and undulatory wear of the rolling surfaces of wheels and rail are highlighted.

\section{Article info}

Received 15 March 2021

Accepted 20 March 2021

Online 27 August 2021

\section{Keywords:}

vibrations,

railway bogie, experimental analysis, root mean square of acceleration, spectral analysis

\section{Introduction}

While running, the railway vehicle is subjected to a permanent vibration regime, with adverse effects on the ride quality, ride comfort, integrity of the goods and traffic safety [1]. The vibrations of railway vehicles are mainly caused by the geometric deviations of the track and by irregularities of the rolling surfaces of the wheels and rails [2-8]. Due to its construction, the track features as a whole, on the one hand, many deviations from the ideal geometrical shape and, on the other hand, defects of the rolling surfaces of the rails. These two above, along with the constructive discontinuities of the rail, make up for the major causes of railway vehicle vibrations [9-14]. Wheel defects, such as eccentricity, oval, polygonal profile, corrugation, flat wheel, flattening or defects of rolling surfaces are also causes of railway vehicle vibrations [15-19].

The vibrations' issues of railway vehicles can be addressed either theoretically or experimentally. From the perspective of a theoretical study, based on the results of numerical simulations, the railway vehicletrack system must be represented by an equivalent mechanical model [20-22]. The railway vehicle is a complex oscillating system, which has specific vibration characteristics [23]. This makes it difficult to represent it through a model with a high degree of reliability, which accurately integrates all the factors that influence the vibration behaviour of a vehicle.
However, the more complex the model, the closer the results would be to reality, but it would make it difficult to draw general conclusions about the vehicle vibration characteristics. Generally, the models for study of the railway vehicle vibrations are obtained through a simplified representation of the vehicle-track system, in which the most important factors that influence the vibration behaviour of ae vehicle are taken into account.

Although the numerical simulations are useful tools for evaluating the vibration behaviour of the railway vehicle from the design phase and then for investigations during the exploitation [24-25], a real estimate of vehicle vibration behaviour can be made only based on the experimental results obtained to circulation on a current track or on a test track. The experimental tests are expensive and require a high investment of time and effort, but the results reflect a real state even of the effects of uncontrollable variables that cannot be highlighted in a study based on numerical simulations [26].

Recent studies, based on the measured data or numerical simulations, have shown that the vehicle dynamic response is correlated with the track irregularities [10, 13, 27-29], which creates the premises of developing certain monitoring methods of track quality or the vehicle condition [30]. The correlation method has been used to highlight the connection between the lateral and vertical axle box acceleration and differently processed track geometry parameters, 


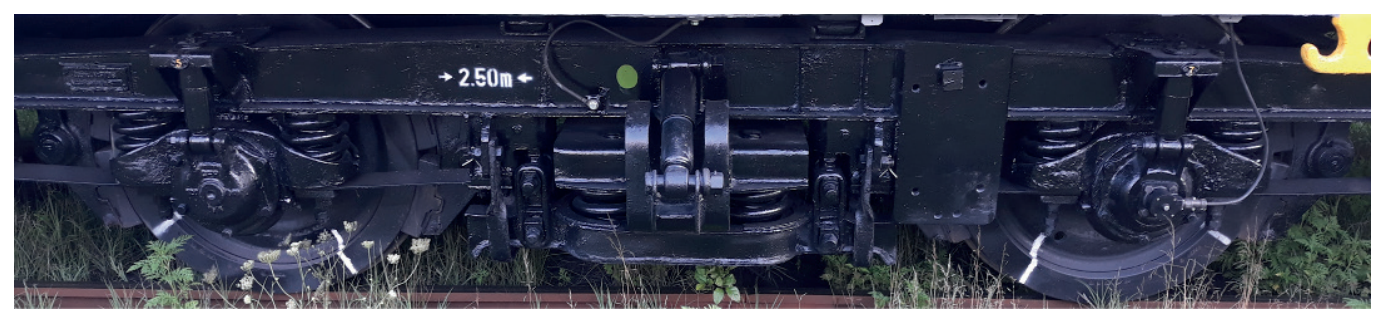

Figure 1 Minden-Deutz bogie

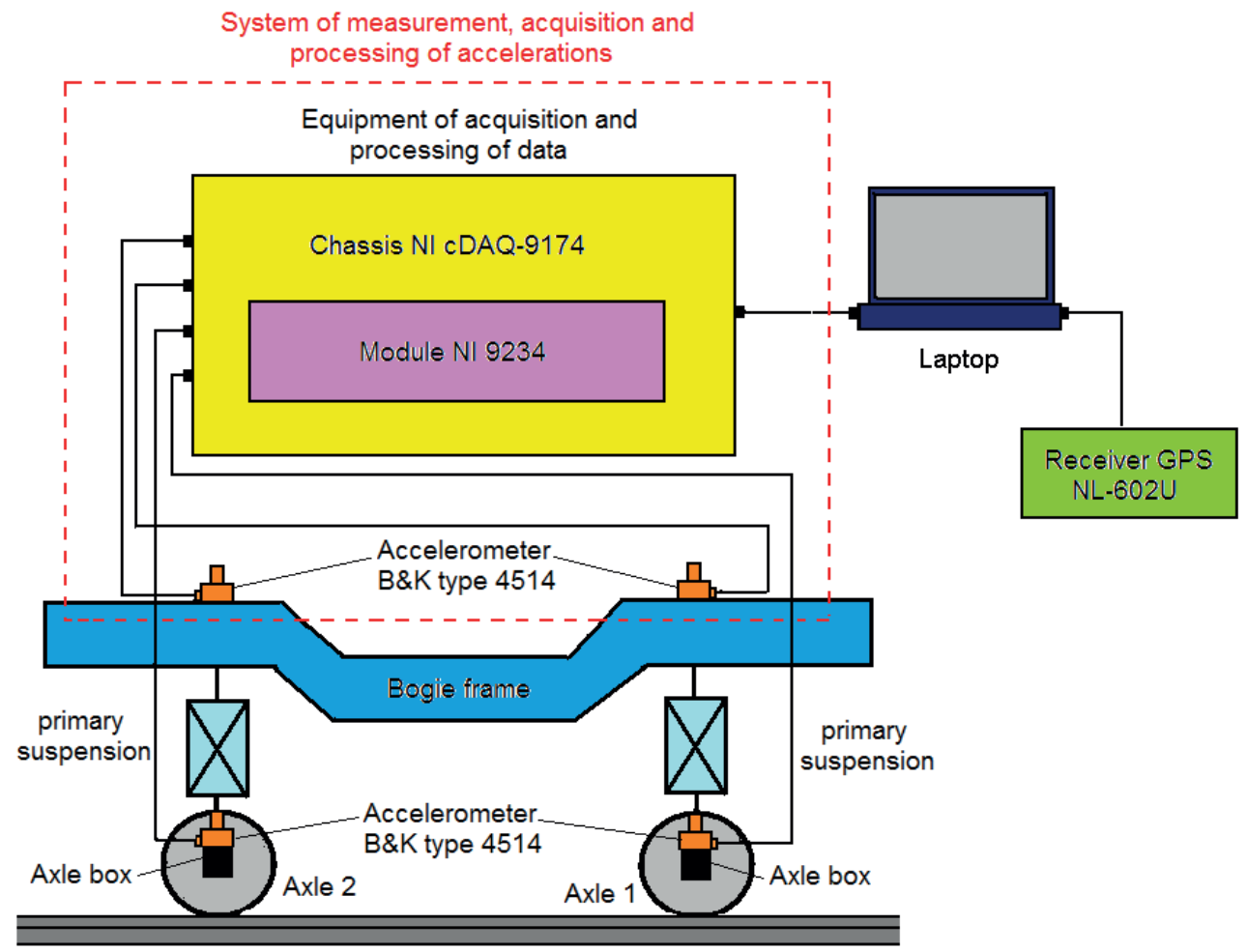

Figure 2 Schematic representation of the measuring chain

based on a measurement run on a straight track [10]. In addition, the correlation between the high-frequency vibrations of the axle box acceleration and the geometry of the rail welds has been used to develop an approach for the real-time health detection of rail welds [29]. The results of the numerical simulations were used for an analysis regarding the correlation between the dynamic response of a two-axle bogie and the track vertical irregularities, based on the Pearson correlation coefficient [13].

This paper presents an analysis of the vertical vibrations of a bogie in a rail passenger vehicle, based on the experimental results obtained by measurements done during the running on a current track, on a doubletrack section in alignment and vertical alignment. In fact, the RMS (root mean square) acceleration is looked at, measured in the axle boxes and on the bogie frame above the axles, for more measurement sequences at a constant velocity. In addition, the spectral analysis of the measured acceleration is done, which helps with $\mathrm{e}$ identification of a series of defects in the wheels and the rolling surfaces of the rail and wheels.

\section{Measurements of the vertical acceleration of a bogie}

The measurements were performed during the running on a current track, for which the maximum traffic velocity is $160 \mathrm{~km} / \mathrm{h}$, on a track section in alignment and vertical alignment. The vertical acceleration of the axles and bogie frames were measured for a passenger railway vehicle equipped with Minden-Deutz bogies (Figure 1). The maximum velocity of the vehicle is $140 \mathrm{~km} / \mathrm{h}$.

The measuring chain, used to measure the vertical acceleration of the axles and the bogie frames, is shown in Figure 2. It includes the components of the measurement, acquisition and processing system for the vertical acceleration, respectively, four 4514 Brüel \& Kjær piezoelectric accelerometers and the set consisting of the NI cDAQ-9174 chassis for the data acquisition and the NI 9234 module for acquisition and synthesising the data from accelerometers. The NL-602U GPS receiver for monitoring and recording the vehicle velocity is also included in the measurement chain. 

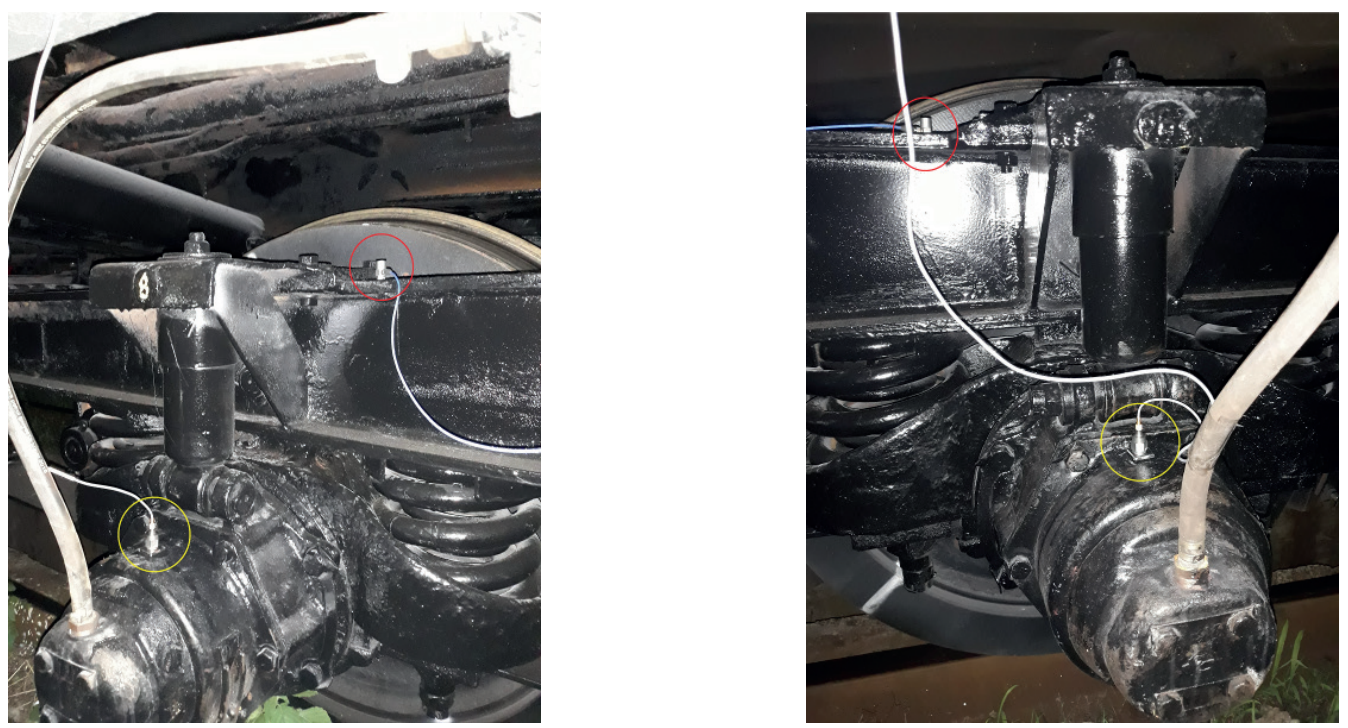

Figure 3 Detail of mounting accelerometers on the bogie frame and the axle boxes
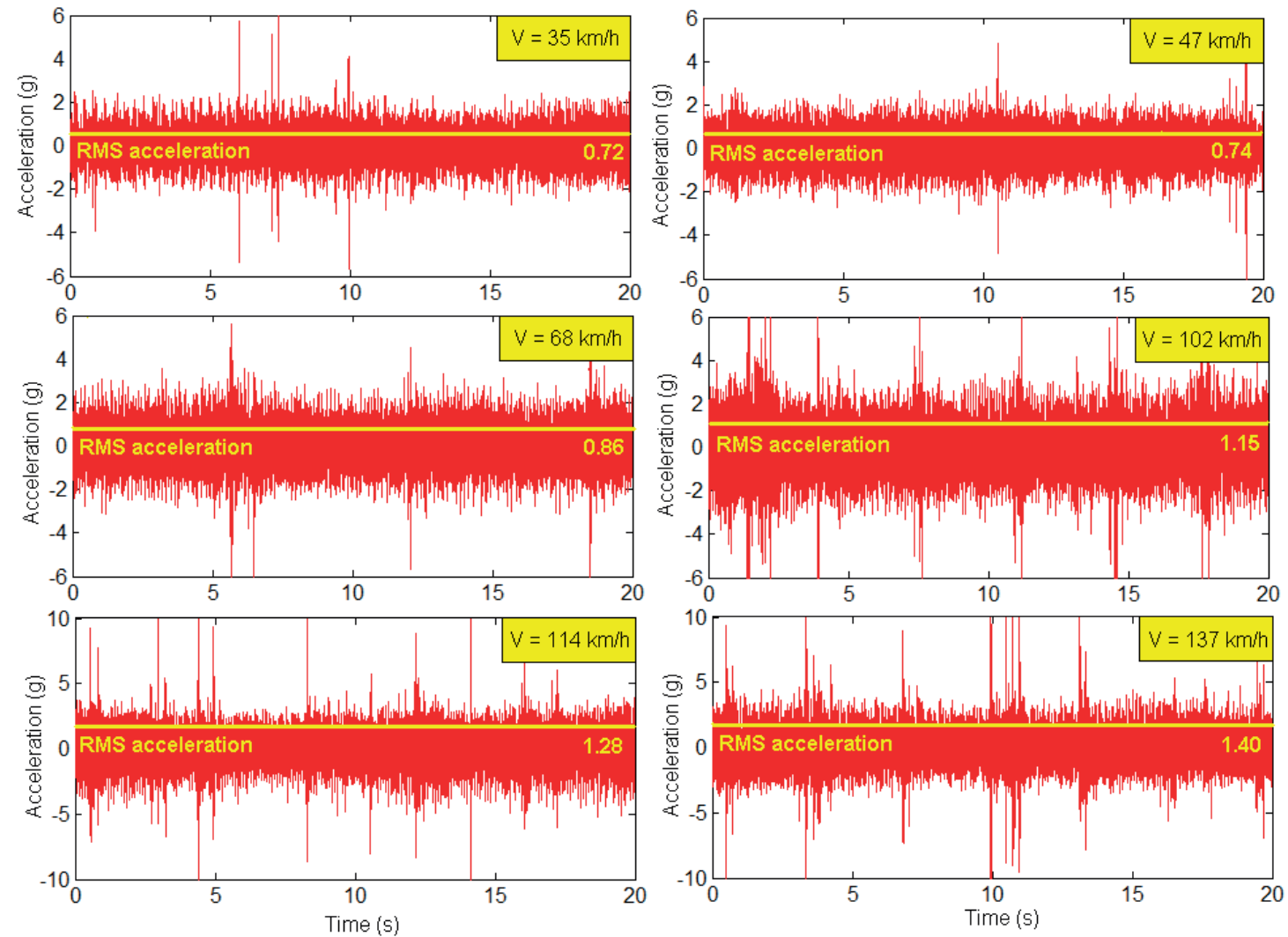

Figure 4 Acceleration recorded on a measurement sequence at axle 1

The accelerometers were mounted on a side of the bogie as follows: one accelerometer on each axle box and one accelerometer on the bogie frame against each axle (Figures 2 and 3) [30-31].

Recordings of acceleration were made at a constant velocity on a distance of circa $60 \mathrm{~km}$ direction of a traffic. The duration of a measurement sequence is 20 seconds, and the sampling frequency is $2048 \mathrm{~Hz}$. The maximum velocity during the measurements was $137 \mathrm{~km} / \mathrm{h}$ on direction 1 and $117 \mathrm{~km} / \mathrm{h}$ on direction 2 .

\section{Analysis of experimental results}

An analysis of the vibrations' characteristics of the axles and the bogie frame, based on the experimental results, is presented in this Section.

In Figures 4 and 5 are presented the accelerations, recorded on a time sequence at different velocities at axle 1 and at the bogie frame above axle 1, respectively. The RMS acceleration is also marked on the diagrams. In all the cases presented, it is observed that the RMS 
accelerations, measured at the axle is circa twice higher than the one measured on the bogie frame. In addition, the results highlight the increase of the RMS acceleration with velocity.
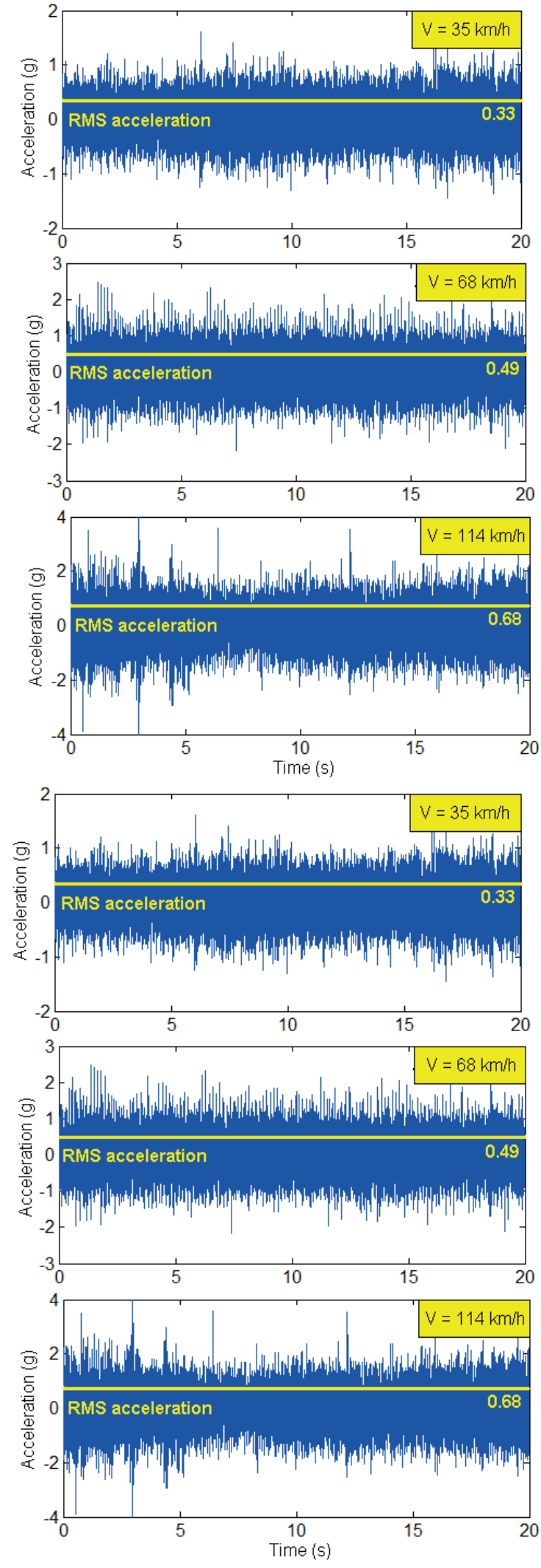

The diagrams in Figure 6 show the spectra of the acceleration measured at the two axles and on the bogie frame for a measurement sequence at a velocity of 137 $\mathrm{km} / \mathrm{h}$, in the frequency range $1-200 \mathrm{~Hz}$. The acceleration
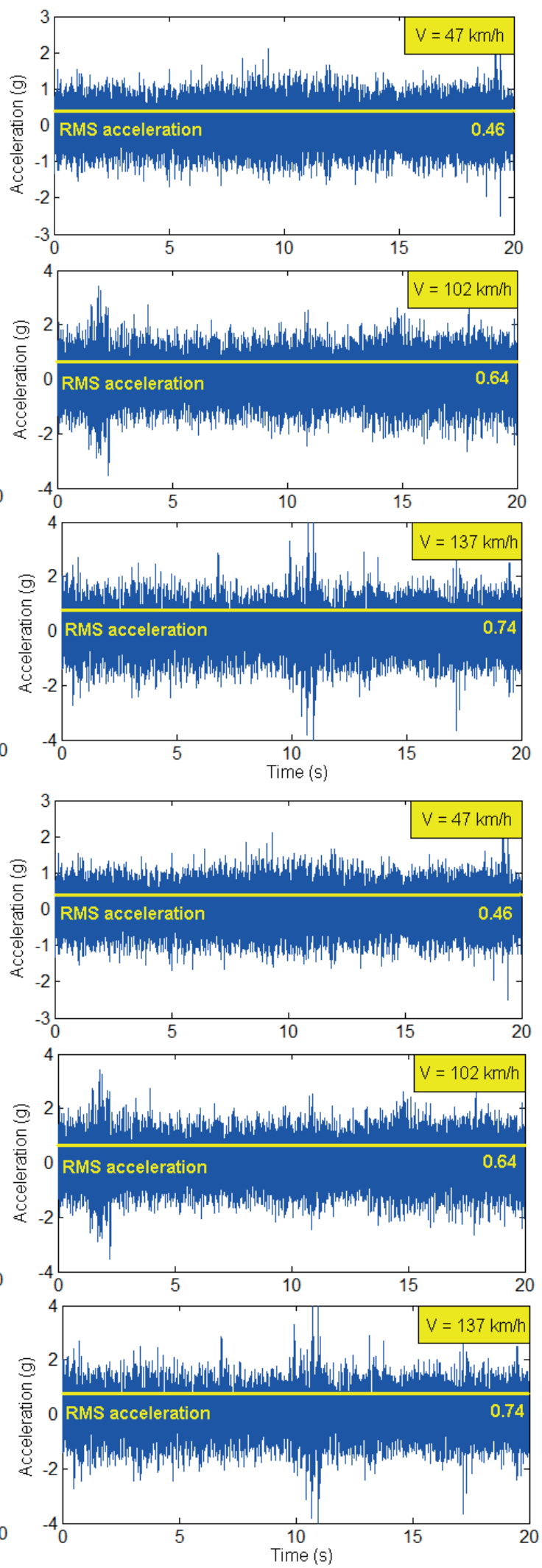

Figure 5 Acceleration recorded on a measurement sequence at the bogie frame above axle 1 
spectra measured at the two axles show several peaks between 6.2 and $150 \mathrm{~Hz}$, the frequency peak at $6.2 \mathrm{~Hz}$ corresponding to the resonant frequency of the bogie bounce. In this frequency range, several accentuated local peaks are observed, which are in arithmetic progression. The first peak corresponds to the frequency of 13.15 $\mathrm{Hz}$ and the other peaks have the following frequencies: $26.25,39.45,52.45,65.85,78.65,91.9,105.3$ and $118.1 \mathrm{~Hz}$. The first peak is due to $\mathrm{y}$ the eccentricity of the wheel, the second due to its ovality and the others due to the undulatory wear from the third order to the ninth order of the rolling surface of the wheel. Another peak occurs at $17.15 \mathrm{~Hz}$, which corresponds to a wavelength of $2.2 \mathrm{~m}$ of irregularities of the rolling surface of the rail, signifying long-wave rail undulatory wear.

The spectra of the acceleration, measured on the bogie frame above the two axles, have a peak at frequency of $6.2 \mathrm{~Hz}$, corresponding to the bounce frequency of the bogie. At frequencies higher than $10 \mathrm{~Hz}$, the dominant peaks of the acceleration spectra are those corresponding to the rolling defects of the wheels or the undulatory wear of the rails listed above.

Figure 7 shows the RMS acceleration of the axles and the bogie frame for 29 measuring sequences at the constant velocity of $117 \mathrm{~km} / \mathrm{h}$. For axle 1, the RMS acceleration is dispersed between $1.12 \mathrm{~g}$ and $1.92 \mathrm{~g}$, whereas for axle 2 , the interval is $1.13 \mathrm{~g}-2.04 \mathrm{~g}$. In the case of the bogie frame, the RMS acceleration is $0.66 \mathrm{~g}-0.92 \mathrm{~g}$ - above the axle 1 and $0.67 \mathrm{~g}-0.97 \mathrm{~g}$ - above the axle 2 . The dispersion of the measured acceleration is due to the variability in the amplitude of the defects along the track.

Figure 8 features the RMS acceleration of the axles and of the bogie frame for 20 measurement sequences at the constant velocity of $137 \mathrm{~km} / \mathrm{h}$. The influence of the defects' variability along the track on the bogies' vibrations is well visible here by having the RMS acceleration divided into two intervals. Corresponding to the measurement sequences 1-12, the RMS accelerations of the axles vary a little, as they are grouped between $1.27 \mathrm{~g}$ and $1.58 \mathrm{~g}$. For the sequence 14, the RMS accelerations of the axles reach a maximum of $2.43 \mathrm{~g}$ - in axle 1 and $2.48 \mathrm{~g}$ - in axle 2. Further on, for the other measurement sequences, the RMS acceleration gradually decrease to $1.69 \mathrm{~g}$ - in axle 1 and to $1.72 \mathrm{~g}$ - in axle 2 .

The RMS acceleration at the bogie frame has the same characteristics as the acceleration of the axles. Above the axle 1, the RMS acceleration is divided into two intervals, with $0.65 \mathrm{~g}-0.75 \mathrm{~g}$ as a first interval, where the accelerations vary a little and another interval where the values decrease from $1.05 \mathrm{~g}$ to $0.79 \mathrm{~g}$. Above the axle 2, the intervals of the RMS acceleration are $0.66 \mathrm{~g}-0.84 \mathrm{~g}$ and $1.13 \mathrm{~g}-0.83 \mathrm{~g}$.

As shown earlier (see Figures 4 and 5) and in the diagrams in Figures 7 and 8, the RMS acceleration of the axles are noticed to be circa twice higher than the ones on the bogie frame. This is quite clear in the diagrams in Figure 9. Plus, the acceleration measured in the two axles is noticed to be unequal. Similarly, the acceleration for the bogie frame above the two axles is not equal, as well. The diagrams in Figure 10 show that the differences between the RMS acceleration of the two axles reach $0.17 \mathrm{~g}$ at the velocity of $117 \mathrm{~km} / \mathrm{h}$, whereas this difference for the bogie frame is $0.06 \mathrm{~g}$ at the most. At $137 \mathrm{~km} / \mathrm{h}$, the differences for the axles come to $0.13 \mathrm{~g}$

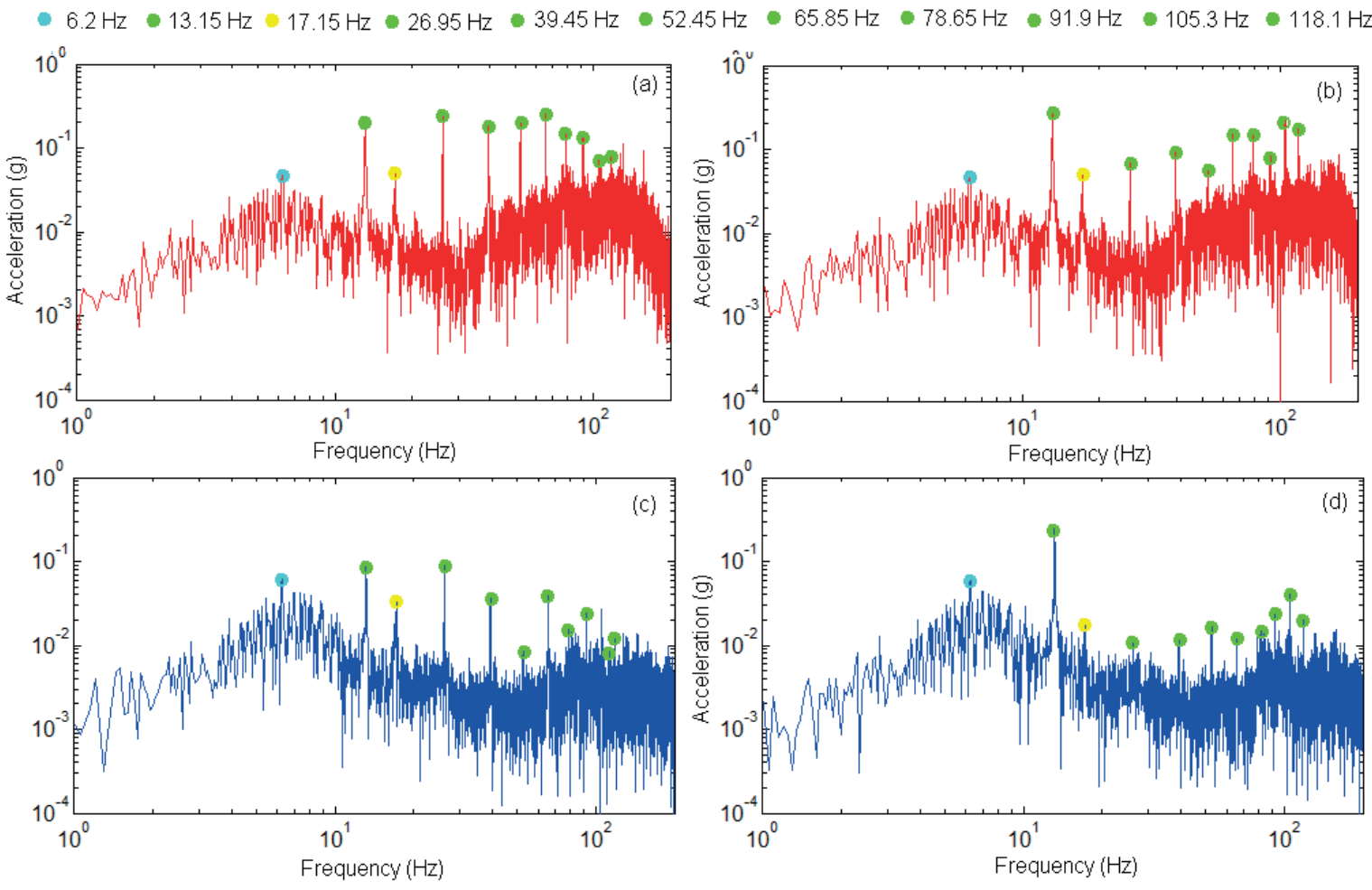

Figure 6 Acceleration spectra measured at velocity of $137 \mathrm{~km} / \mathrm{h}:$ (a) at axle 1; (b) at axle 2; (c) on the bogie frame above the axle 1; (d) on the bogie frame above the axle 2 

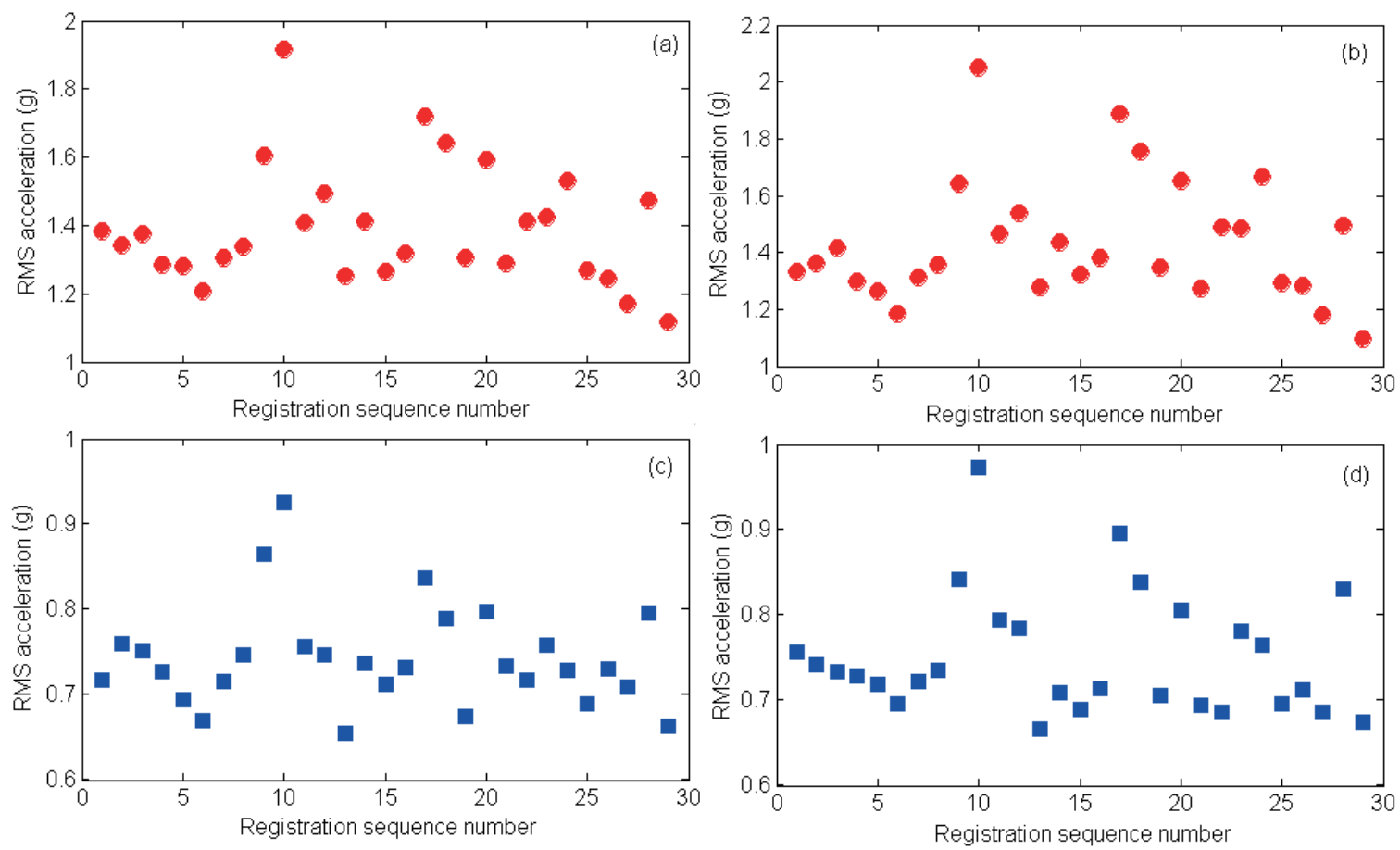

Figure 7 The RMS acceleration at velocity of $117 \mathrm{~km} / \mathrm{h}$ for 29 measurement sequences: (a) at axle 1;

(b) at axle 2; (c) on the bogie frame above the axle 1; (d) on the bogie frame above the axle 2
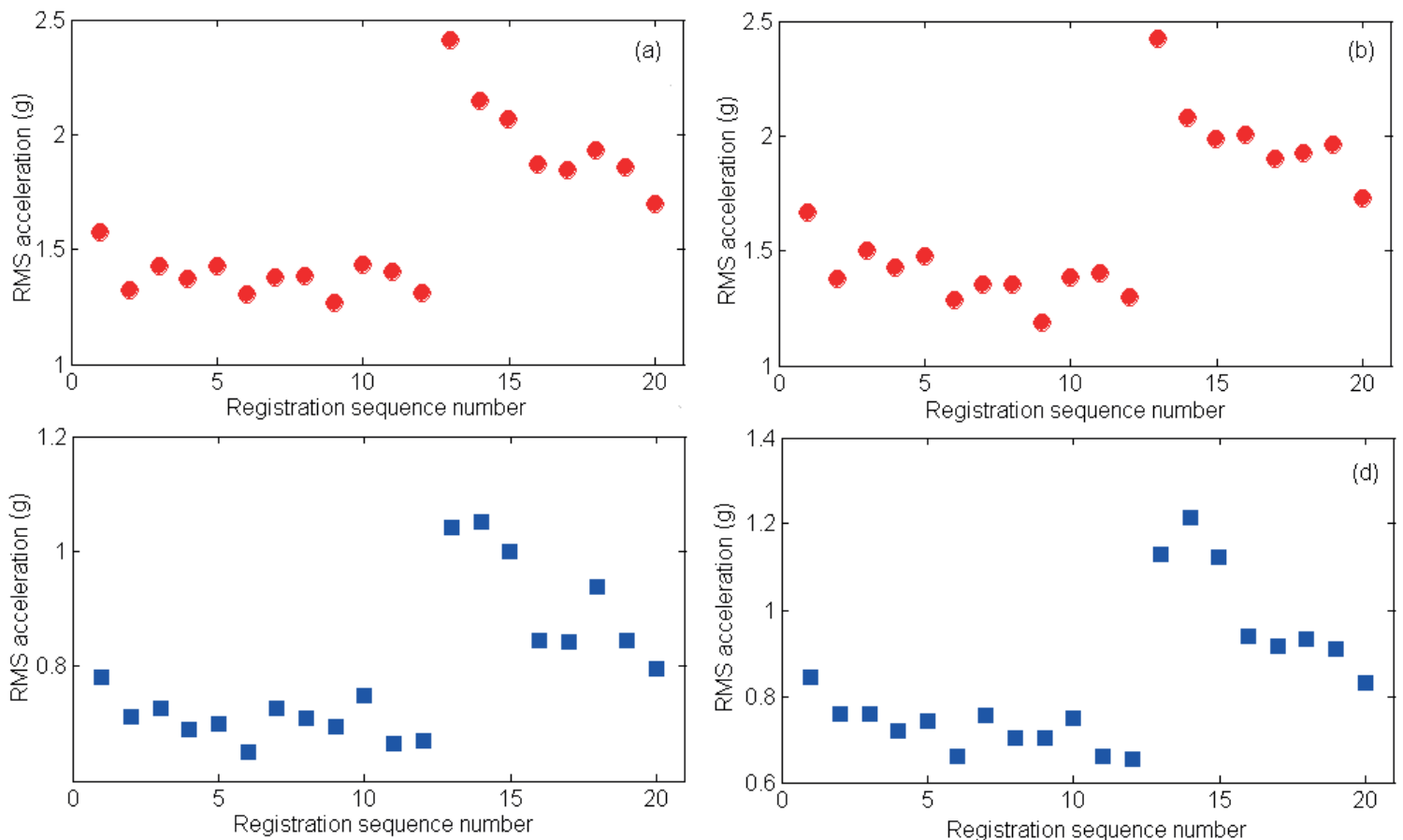

Figure 8 The RMS acceleration at velocity of $137 \mathrm{~km} / \mathrm{h}$ for 29 measurement sequences:

(a) at axle 1; (b) at axle 2; (c) on the bogie frame above the axle 1; (d) on the bogie frame above the axle 2

and for the RMS acceleration measured on the bogie frame, the value arrives at $0.17 \mathrm{~g}$.

\section{Conclusions}

In this paper, the vertical vibrations of the axles and the bogie frame of a passenger vehicle were analysed. The analysis was based on the RMS acceleration for more measurement sequences at two constant velocities. The results showed the fact that the RMS acceleration are circa twice higher in the axles than in the bogie frame. In addition, the RMS acceleration has been proven to increase along with the velocity.

The analysis of the RMS acceleration for more measurement sequences at the same velocity has made visible the influence of the track defects on the 

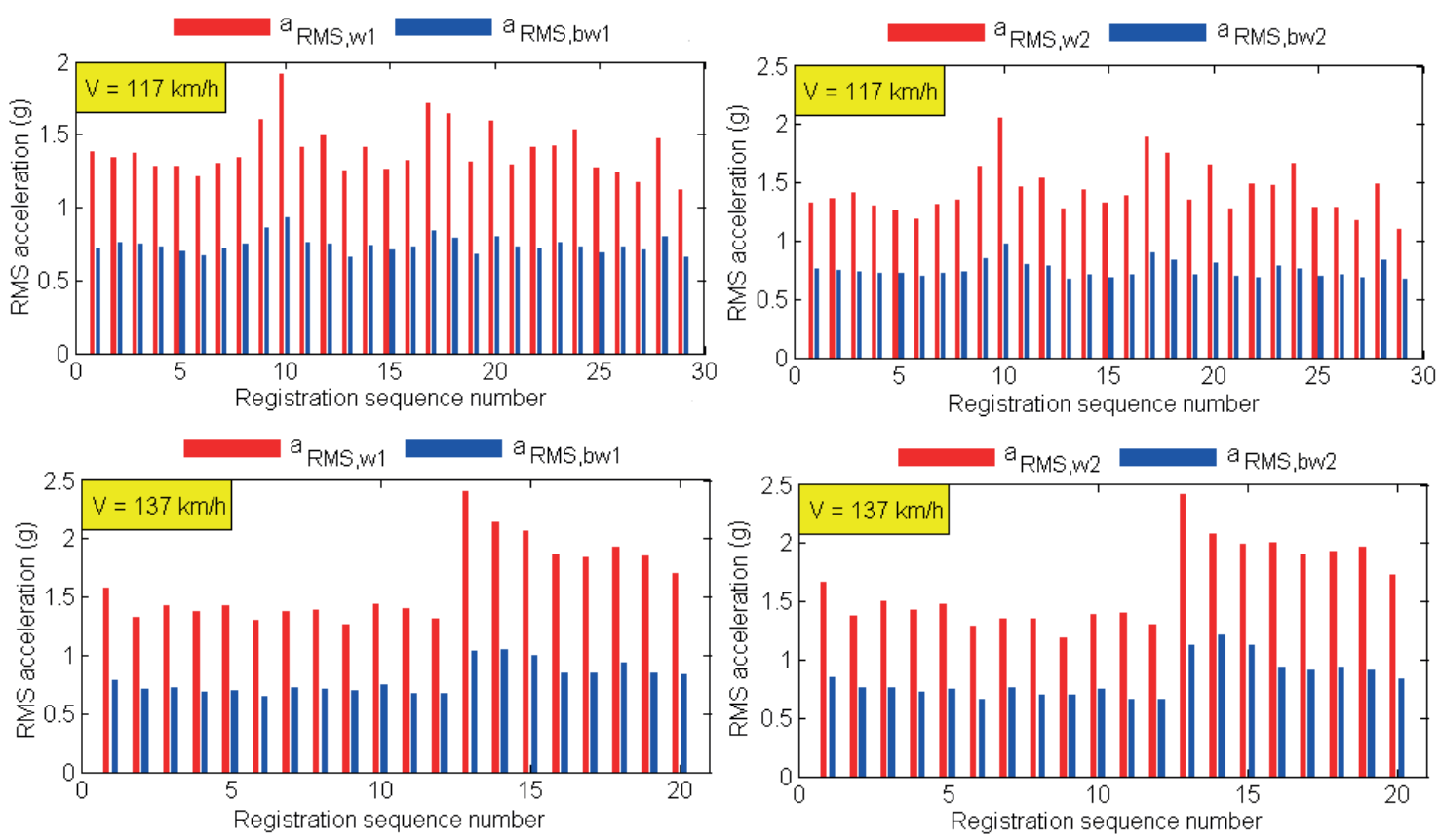

Figure 9 The RMS acceleration: $a_{R M S, w 1,2}-R M S$ acceleration of the axles; $a_{R M S, b w 1,2}-R M S$ acceleration of the bogie frame above the axles 1 and 2
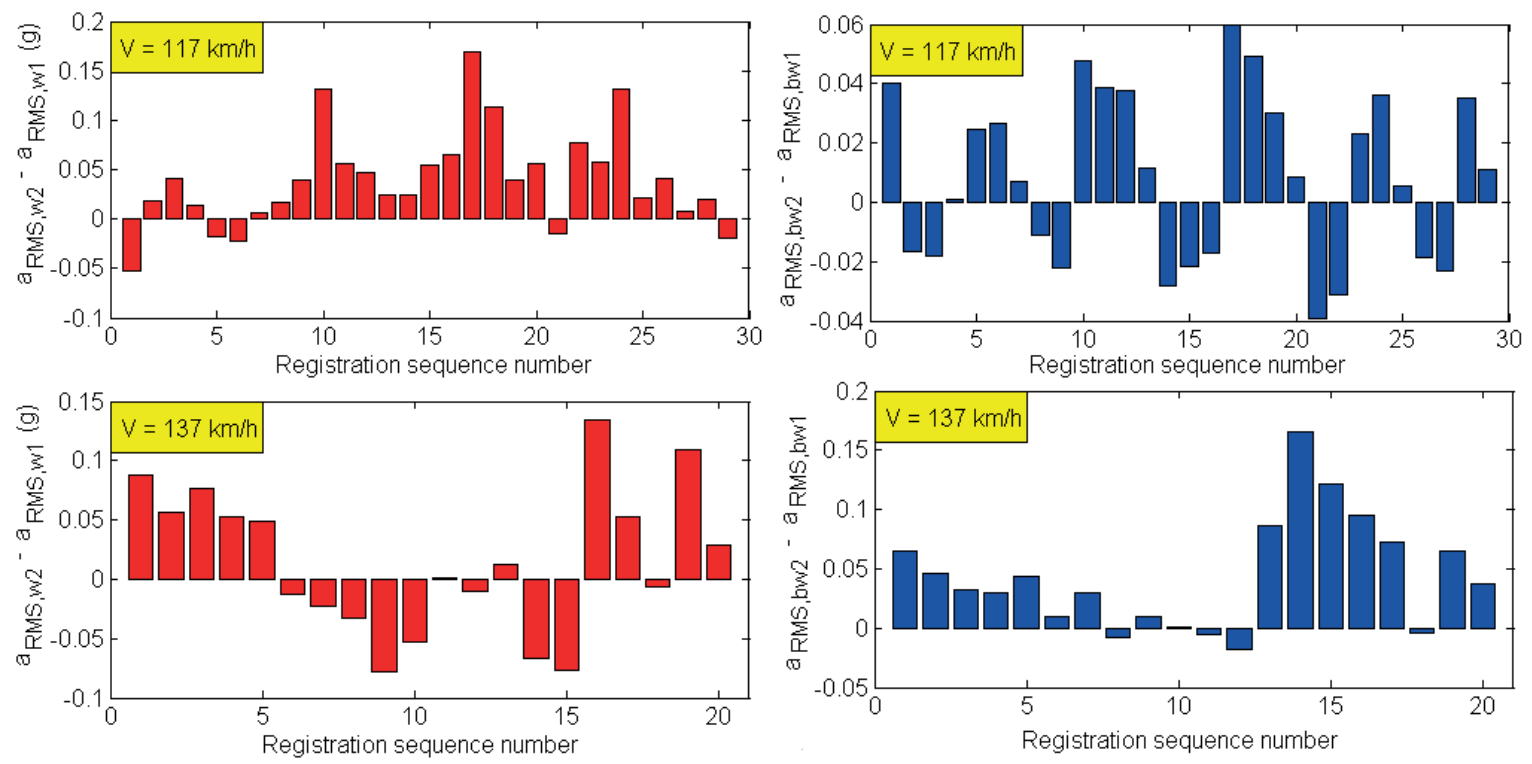

Figure 10 The difference between the RMS acceleration: $a_{R M S, 12}-R M S$ acceleration of the axles; $a_{R M S, b w 1,2}-R M S$ acceleration of the bogie frame above axles 1 and 2

bogie vibrations. Due to the variability in the defects amplitude along the track, the RMS acceleration are not equal at the same velocity, as they are dispersed on interval of circa $0.03 \mathrm{~g}$ to $0.9 \mathrm{~g}$.

Based on the spectral analysis of the measured accelerations, wheel defects were identified, namely, eccentricity and ovality and undulatory wear of the rolling surfaces of wheels and rail.
Future research may be aimed at analysis of correlation between the railway bogie vibrations and axles vibrations, based on the measured acceleration. The existence of a correlation between the accelerations measured on the axle boxes and the accelerations measured on the bogie frame may be the basis for development of a method for the condition monitoring of the vehicle primary suspension.

\section{References}

[1] SEBESAN, I., MAZILU, T. Vibrations of the railway vehicles (in Romanian). Bucharest: MatrixRom, 2010. ISBN 978-973-755-332-4. 
[2] XU, L., ZHAI, W., GAO, J., MEACCI, M., CHEN, X. On effects of track random irregularities on random vibrations of vehicle-track interactions. Probabilistic Engineering Mechanics [online]. 2017, 50, p. 25-35 [accessed 2021-03-15]. ISSN 0266-8920. Available from: https://doi.org/10.1016/j.probengmech.2017.10.002

[3] CHELI, F., CORRADI, R. On rail vehicle vibrations induced by track unevenness: analysis of the excitation mechanism. Journal of Sound and Vibration [online]. 2011, 330, p. 3744-3765 [accessed 2021-03-15]. ISSN 0022-460X. Available from: https://doi.org/10.1016/j.jsv.2011.02.025

[4] YOUNG, T. H., LI, C. Y. Vertical vibration analysis of vehicle/imperfect track systems. Vehicle System Dynamics [online]. 2003, 40(5), p. 329-349 [accessed 2021-03-15]. ISSN 0042-3114. Available from: https://doi.org/10.1076/ vesd.40.5.329.17912

[5] DUMITRIU, M. Analysis of the dynamic response in the railway vehicles to the track vertical irregularities. Part I: the numerical analysis. Journal of Engineering Science and Technology Review [online]. 2015, 8(4), p. 24-31 [accessed 2021-03-15]. ISSN 1791-2377. Available from: http://www.jestr.org/downloads/Volume8Issue4/ fulltext8442015.pdf

[6] DUMITRIU, M. Analysis of the dynamic response in the railway vehicles to the track vertical irregularities. Part II: the numerical analysis. Journal of Engineering Science and Technology Review [online]. 2015, 8(4), p. 32-39 [accessed 2021-03-15]. ISSN 1791-2377. Available from: http://www.jestr.org/downloads/Volume8Issue4/ fulltext8452015.pdf

[7] DUMITRIU, M., SEBESAN, I. On the wheelset vibration due to the stochastic track vertical irregularities. Applied Mechanics and Materials [online]. 2015, 809-810, p. 1037-1042 [accessed 2021-03-15]. ISSN 1662-7482. Available from: https://doi.org/10.4028/www.scientific.net/AMM.809-810.1037

[8] MAZILU, T. On the dynamic effects of wheel running on discretely supported rail. Proceedings of the Romanian Academy, Series A: Mathematics, Physics, Technical Sciences, Information Science [online]. 2009, 10(3), p. 269-276 [accessed 2021-03-15]. ISSN 1454-9069. Available from: https://acad.ro/sectii2002/proceedings/ doc2009-3/09-Mazilu.pdf

[9] MAZILU, T. Analysis of infinite structure response due to moving wheel in the presence of irregularities via Green's functions method. Proceedings of the Romanian Academy, Series A: Mathematics, Physics, Technical Sciences, Information Science [online]. 2009, 10(2) p. 139-150 [accessed 2021-03-15]. ISSN 1454-9069. Available from: https://acad.ro/sectii2002/proceedings/doc2009-2/06-Mazilu.pdf

[10] AGH, C. Comparative analysis of axlebox acceleration in correlation with track geometry irregularities. Acta Technica Jaurinensis [online]. 2019, 12(2), p. 161-177 [accessed 2021-03-15]. ISSN 2064-5228. Available from: https://doi.org/10.14513/actatechjaur.v12.n2.501

[11] XU, L., ZHAI, W., GAO, J. A probabilistic model for track random irregularities in vehicle/track coupled dynamics. Applied Mathematical Modelling [online]. 2017, 51, p. 145-158 [accessed 2021-03-15]. ISSN 0307-904X. Available from: https://doi.org/10.1016/j.apm.2017.06.027

[12] POMBO, J., AMBROSIO, J. An alternative method to include track irregularities in railway vehicle dynamic analyses. Nonlinear Dynamics [online]. 2012, 68, p. 161-176 [accessed 2021-03-15]. ISSN 1573-269X. Available from: https://doi.org/10.1007/s11071-011-0212-2

[13] DUMITRIU, M., FOLOGEA, D. Numerical analysis on the correlation between bogie dynamic response and vertical track irregularities. UPB Scientific Bulletin, Series D: Mechanical Engineering [online]. 2019, 81(4), p. 99-110. ISSN 1454-2358. Available from: https://www.scientificbulletin.upb.ro/rev_docs_arhiva/ rez1fd_907572.pdf

[14] DUMITRIU, M., CRUCEANU, I. C. Effect of vertical track irregularities on the vibration of railway bogie. UPB Scientific Bulletin, Series D: Mechanical Engineering [online]. 2019, 81(1), p. 67-78. ISSN 1454-2358. Available from: https://www.scientificbulletin.upb.ro/rev_docs_arhiva/full866_449125.pdf

[15] SHAN, W., WU, P., WU, X., ZHANG, F., SHI, H. Effect of wheel polygonization on the axle box vibrating and bolt self-loosening of high-speed trains. IOP Conference Series: Journal of Physics: Conference Series [online]. 2019, 1213, 052044. ISSN 1742-6596. Available from: https://doi.org/ 0.1088/1742-6596/1213/5/052044

[16] PENG, B., IWNICKI, S., SHACKLETONA, P., CROSBEE, D., ZHAO, Y. The influence of wheelset flexibility on polygonal wear of locomotive wheels. Wear [online]. 2019, 432-433, 102917. ISSN 0043-1648. Available from: https://doi.org/10.1016/j.wear.2019.05.032

[17] MAZILU, T., DUMITRIU, M., TUDORACHE, C., SEBESAN, M. Wheel/rail interaction due to the polygonal wheel. UPB Scientific Bulletin, Series D, Mechanical Engineering [online]. 2011, D(3), p. 95-108. ISSN 1454-2358. Available from: https://www.scientificbulletin.upb.ro/rev_docs_arhiva/full81732.pdf

[18] MAZILU, T. A dynamic model for the impact between the wheel flat and rail. UPB Scientific Bulletin Series D: Mechanical Engineering [online]. 2007, 69(2), p. 45-58. ISSN 1454-2358. Available from: https://www.scientificbulletin.upb.ro/rev_docs_arhiva/full58723.pdf 
[19] MAZILU, T. Geometric model of a railway wheel with irregular contour. Advances in Intelligent Systems and Computing [online]. 2016, 356, p. 155-166. ISSN 2194-5357. Available from: https://doi.org/10.1007/978-3-31918296-4_13

[20] CLAUS, H., SCHIEHLEN, W. Modelling and simulation of railway bogie structural vibrations. Vehicle System Dynamics[online].1998,28,p.538-552.ISSN0042-3114.Availablefrom:https://doi.org/10.1080/00423119808969585

[21] DUMITRIU, M. Modelling of railway vehicles for virtual homologation from dynamic behavior perspective. Applied Mechanics and Materials [online]. 2013, 371, p. 647-651. ISSN 1662-7482. Available from: https://doi.org/10.4028/www.scientific.net/AMM.371.647

[22] EICKHOFF, B. M., EVANS, J. R., MINNIS, A. J. A review of modelling methods for railway vehicle suspension components. Vehicle System Dynamics [online]. 1995, 24(6-7), p. 469-496. ISSN 0042-3114. Available from: https://doi.org/10.1080/00423119508969105

[23] DIANA, G., CHELI, F., COLLINA, A., CORRADI, R., MELZI, S. The development of a numerical model for railway vehicles comfort assessment through comparison with experimental measurements. Vehicle System Dynamics [online]. 2002, 38(3) p. 165- 183. ISSN 0042-3114. Available from: https://doi.org/ 10.1076/vesd.38.3.165.8287

[24] EVANS, J., BERG, M. Challenges in simulation of rail vehicle dynamics. Vehicle System Dynamics [online]. 2009, 47, p. 1023-1048. ISSN 0042-3114. Available from: https://doi.org/10.1080/00423110903071674

[25] SCHUPP, G. Simulation of railway vehicles: necessities and applications. Mechanics based design of structures and machines [online]. 2003, 31(3), p. 297-314. ISSN 1539-7734. Available from: https://doi.org/10.1081/SME120022852

[26] UIC 518 Leaflet. Testing and approval of railway vehicles from the point of view of their dynamic behaviour safety - track fatigue - running behaviour. 2009

[27] KARIS, T., BERG, M., STICHEL, S., LI, M., THOMAS, D., DIRKS, B. Correlation of track irregularities and vehicle responses based on measured data. Vehicle System Dynamics [online]. 2018, 56(6), p. 967-981. ISSN 0042-3114. Available from: https://doi.org/10.1080/00423114.2017.1403634

[28] KARIS, T., BERG, M., STICHEL, S. Analysing the correlation between vehicle responses and track irregularities using dynamic simulations and measurements. Proceedings of the Institution of Mechanical Engineers, Part F: Journal of Rail Rapid Transit [online]. 2020, 234(2), p. 170-182. ISSN 0954-4097. Available from: https://doi.org/10.1177/0954409719840450

[29] BOYANG, A., WANG, P. J., XU, CHEN, R., CUI, D. Observation and simulation of axle box acceleration in the presence of rail weld in high-speed railway. Applied Sciences [online]. 2017, 7, 1259. ISSN 2076-3417. Available from: https://doi.org/10.3390/app7121259

[30] DUMITRIU, M. Fault detection of damper in railway vehicle suspension based on the cross-correlation analysis of bogie accelerations. Mechanics and Industry [online]. 2019, 20(1), 10. ISSN 2257-7777. Available from: https://doi.org/10.1051/meca/2018051

[31] DUMITRIU, M. RACANEL, I. R. Experimental verification of method to synthesize the track vertical irregularities. Romanian Journal of Transport Infrastructure [online]. 2018, 7(2), p. 40-60. ISSN 2286-2218. Available from: https://doi.org/10.2478/rjti-2018-0011 